\title{
PENGOLAHAN LIMBAH TERNAK DI KELOMPOK PETERNAK MAULAFA
}

\section{Tri Anggarini Y. Foenay, Theresia Nur Indah Koni}

\author{
Politeknik Pertanian Negeri Kupang \\ e-mail: anggarini.foenay@gmail.com,indahkoni@gmail.com
}

\begin{abstract}
ABSTRAK
Tujuan dari kegiatan pengabdian pada masyarakat ini agar peternak dapat memanfaatkan limbah yang dihasilkan dari usaha peternak menjadi bahan yang memberikan manfaat bagi peternak dan untuk mengurangi pencemaran yang dihasilkan dari usaha peternak. Metode yang digunakan dalam kegiatan ini adalah penyuluhan, pelatihan, demplot,monitoring dan evaluasi. Dalam IbM selain dilakukan proses pengolahan limbah peternak juga diberi pengetahuan tentang pemeliharaan ternak bibit, penanganan kelahiran, perkandangan yang sesuai untuk pembibitan serta ini dilakukan beberapa kegiatan seperti perbaikan kandang, pengadaan bibit ternak, penyuluhan, pembuatan pakan, perkawinan ternak, penanganan kelahiran ternak, penjualan anak babi.
\end{abstract}

Kata kunci : bokashi, limbah, Maulafa, pengabdian

\section{PENDAHULUAN}

Salah satu sumber protein hewani bagi masyarakat Nusa Tenggara Timur (NTT) adalah daging babi. Ternak babi biasanya digunakan dalam acara-acara adat. Masyarakat NTT umumnya selalu memelihara ternak ini dengan jumlah pemeliharaan 2-10 ekor per rumah tangga. Hampir semua rumah tangga memelihara ternak babi dan pada suatu usaha peternakan akan dihasilkan limbah, baik limbah cair maupun limbah padat. Limbah ini umumnya berasal dari kotoran ternak, sisa pakan dan urine yang dapat menyebabkan terjadinya pencemaran serta mengganggu lingkungan sekitarnya jika tidak dikelola dengan baik. Limbah ternak atau peternakan adalah 
semua yang berasal dari ternak atau petenakan baik bahan padat maupun cair, yang belum dimanfaatkan dengan baik. Adapun yang termasuk dalam limbah ternak adalah tinja atau feses dan air kencing atau urin.

Limbah ternak sangat banyak mengandung nutrien yang penting bagi tanah, pupuk yang dihasilkan dari berbagai feses ternak pun menghasilkan nutrien seperti fosfor dan kalium yang tinggi. Kusuma (2012) menyatakan bahwa kandungan fosfor bokashi dari feses ternak babi lebih tinggi daripada ternak kambing dan sapi, masing-masing 3,23\% pada ternak babi, 1,634\% pada ternak kambing dan 1,905\% pada ternak sapi. Limbah peternakan ini tentu saja tidak langsung digunakan pada tanaman tetapi harus diolah dulu, seperti dijadikan pupuk bokashi. Bokashi merupakan pupuk organik yang diproduksi secara cepat yang dilakukan melalui hasil fermentasi dengan menggunakan teknologi EM-4 (effective microorganism turunan ke-empat) (Marsudi, 2011). Dinesh et al. (2010) mengemukakan bahwa penggunaan bahan organik sebagai pupuk dan meningkatkan biologi tanah sehingga tanah menjadi lebih subur.

Pangarimbun et al. (2012) mengemukakan bahwa pemupukan dapat meningkatkan hasil tanaman tomat, pemberian pupuk organik dari limbah peternakan dapat mengurangi biaya usaha tani. Selain itu Annisava (2013) menyatakan bahwa peningkatan hasil tanaman sayuran tergantung pada pemupukan dan penggunaan pestisida, untuk mengurangi residu kimia pada hasil pertanian maka sebaiknya menggunakan bahan-bahan pupuk dan pestisida organik.

Kegiatan Ipteks bagi Masyarakat (IbM) ini memiliki kelompok yang berusaha dalam pembibitan ternak babi. Mitra memiliki 3 ekor ternak babi yang dapat menghasilkan limbah cukup banyak setiap harinya. Limbah tersebut belum diolah secara baik sehingga dapat mengganggu kenyamanan warga sekitar karena bau yang dihasilkan. Limbah ternak dari kandang dialirkan ke lubang pembuangan yang ada dekat kandang dan dibiarkan saja hingga padat dan bila sudah berbentuk seperti tanah kemudian diambil untuk digunakan sebagai pupuk. Proses pengolahan limbah menjadi pupuk seperti ini tidak hanya memerlukan waktu yang sangat lama tetapi juga mengganggu lingkungan karena letak kandang yang berdekatan dengan pemukiman penduduk. sehingga pada kegiatan pengabdian ini, selain diberi penyuluhan 
mengenai cara beternak babi yang baik diberikan juga tentang pemanfaatan limbah untuk dijadikan pupuk, sehingga petani dapat mempersingkat waktu yang dibutuhkan agar limbah tersebut dapat digunakan.

\section{MASALAH}

Permasalahan yang dihadapi oleh mitra diketahui melalui diskusi maupun pengamatan langsung pada lokasi kegiatan pengabdian, sehingga beberapa masalah yang dihadapi dalam pengelolaan limbah ternak babi dapat diidentifikasi sebagai berikut : 1) lokasi usaha pembibitan ternak babi oleh mitra berada dekat dengan pemukiman, sehingga dapat berdampak negatif terhadap lingkungan sekitar, 2) limbah ternak yang dihasilkan tidak diolah tetapi dibiarkan dalam lubang pembuangan hingga padat dan setelah itu diangkat untuk dijadikan pupuk. Cara pembuatan pupuk seperti ini membutuhkan waktu lama agar limbah dapat dimanfaatkan sebagai pupuk, 3) kurangnya pengetahuan mengenai penanganan dan pengolahan limbah menjadi salah satu penyebab permasalahan yang dihadapi mitra.

\section{METODE PELAKSANAAN}

Metode pendekatan yang digunakan untuk menyelesaikan permasalahan mitra yang telah disepakati bersama adalah :

a. Metode ceramah, dengan menyampaikan informasi ipteks secara lisan kepada mitra yang pada umumnya mengikuti secara pasif. Informasi ipteks disampaikan oleh tim IbM. Materi diberikan dalam bentuk leaflet dan disampaikan juga secara lisan pada kegiatan penyuluhan.

b. Metode diskusi. Mitra berdiskusi dengan tim IbM dan nara sumber terkait materi yang telah diberikan.

c. Metode praktek. Tim IbM memberikan kesempatan kepada mitra secara berkelompok untuk dilatih melakukan suatu proses. Tim IbM bersama-sama dengan semua anggota kelompok tani mempraktekkan pembuatan pupuk bokashi yang berasal dari limbah ternak.

d. Metode pendampingan, tim IbM melakukan pendampingan hingga tujuan IbM ini tercapai. 
Bahan- bahan yang diperlukan dalam pembuatan bokashi pupuk kandang yaitu kotoran ternak (sapi dan babi) $200 \mathrm{~kg}$, sekam padi $25 \mathrm{~kg}$, dedak padi $25 \mathrm{~kg}$, gula pasir 250 gram, EM4 $100 \mathrm{ml}$, dan air secukupnya.

Prosedur pembuatan bokashi yaitu

1. Gula dilarutkan dengan menggunakan air panas.

2. Setelah gulanya terlarut, tambahkan air dingin.

3. Mikrobia pengurai yaitu EM4 dimasukkan kedalam larutan gula, campurkan hingga homogen.

4. Campurkan kotoran ternak, sekam dan dedak padi hingga homogen.

5. 5. Percikan larutan EM4 secara perlahan-lahan ke dalam campuran bahan secara merata sampai kandungan air mencapai 30\%. Indikatornya yaitu dengan menggenggam bahan, apabila tidak menetes dan akan mekar bila genggaman dilepaskan maka kandungan airnya sudah sesuai.

6. Masukkan semua bahan ke dalam karung atau campuran tersebut kemudian ditutup dan didiamkan untuk mengalami proses dekomposisi selama 14 hari dan pembalikan dilakukan setiap 2 hari.

7. Bila bokashi terlihat kering maka saat pembalikan diperciki dengan air.

8. Bokhasi yang telah matang dan siap untuk digunakan memiliki ciri berwarna hitam, gembur tidak panas dan tidak berbau. Sebelum digunakan sebaiknya pupuk dianginanginkan terlebih dahulu dan suhunya sama dengan suhu ruangan.

\section{HASIL DAN PEMBAHASAN}

Kegiatan pembuatan pupuk bokashi di kelompok tani Maulafa telah dilaksanakan dengan tahapan-tahapan sebagai berikut:

\section{Koordinasi Kegiatan}

Koordinasi dengan mitra dilakukan 
oleh tim pelaksana untuk menyepakati tentang apa yang harus disiapkan dalam

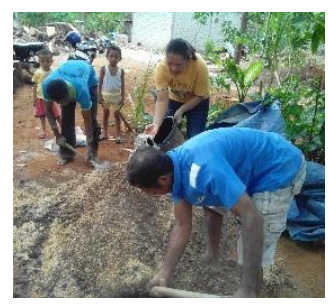

Gambar 1. Pembuatan Pupuk bokashi di Maulafa

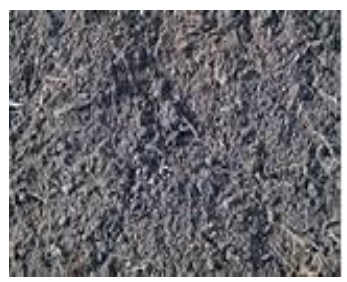

Gambar 2. Pupuk bokashi setelah pemeraman 14 hari pembuatan pupuk, jadwal pelaksanaan, serta bentuk peran mitra dan tim IbM.

Sebelum dilakukan kegiatan penyuluhan bahan-bahan untuk pembuatan pupuk bokashi pun disiapkan, bahan-bahan yang digunakan antara lain kotoran babi yang telah kering, kotoran sapi, sekam padi, dedak padi, gula pasir EM 4, sedangkan peralatan yang digunakan yaitu terpal, sekop, ember, karung.

Sebelum dilakukan praktek pembuatan pupuk organik didahului dengan kegiatan penyuluhan dilakukan oleh tim pelaksana IbM tentang proses pengolahan pupuk, selain itu cara pembuatannya pupuk ini diberikan dalam bentuk leaflet agar anggota kelompok lebih mudah memahaminya.

Pada kegiatan penyuluhan ini mitra mendengarkan penjelasan tim pelaksana IbM kemudian dilanjutkan dengan diskusi, dimana mitra bertanya tentang hal-hal yang kurang dipahami 
terutama yang berhubungan dengan materi yang dibawakan, dan dicarikan solusinya oleh tim pelaksana IbM.

\section{Demplot dan Pendampingan}

Kegiatan demonstrasi plot (demplot) dilakukan secara langsung oleh tim pelaksana yang dibantu oleh mahasiswa dan anggota kelompok tani. Kegiatan tersebut lebih mudah dipahami oleh masyarakat karena langsung dipraktekkan bersama-sama dengan tim IbM. Demplot yang dilakukan adalah pembuatan pupuk bokashi sebanyak $250 \mathrm{~kg}$.

\section{Monitoring dan Evaluasi}

Dalam rangka mensukseskan kegiatan IbM, maka tim pelaksana selalu melakukan monitoring dan evaluasi (Monev) terhadap setiap tahapan kegiatan. Monev dilakukan untuk memantau perkembangan usaha peternak babi mitra. Permasalahan yang ditemui dalam kegiatan monitoring segera diselesaikan secara bersama-sama.

\section{KESIMPULAN}

Berdasarkan hasil kegiatan yang telah dilaksanakan maka dapat disimpulkan bahwa kegiatan pembuatan pupuk bokashi pada mitra peternak babi Maulafa ini telah terlaksana dengan baik dan berhasil. Bokashi yang dihasilkan dapat dimanfaatkan untuk keperluan mitra, sehingga mengurangi dampak pencemaran disekitar kandang ternak babi mitra. 


\section{DAFTAR PUSTAKA}

Annisava A.R. 2013. Optimalisasi pertumbuhan dan kandungan vitamin c kailan (Brassica alboglabra L.) menggunakan bokashi serta ekstrak tanaman terfermentasI. Jurnal Agroteknologi. 3 (2):1-10

Dinesh, R., V. Srinivasan, S. Hamza, A.Manjusha. 2010.Short-term incorporation of organic manures andbiofertilizers influences biochemical and microbial characteristics of soils under an annual crop turmeric (Curcuma longa L.). Bioresource Technol. 101:46974702 .

Kusuma, ME. 2012. Pengaruh Beberapa Jenis upuk Kandang Terhadap Kualitas Bokashi. Jurnal Ilmu Hewani Tropika 1(2): 41-46.

Marsudi E. 2011. Analisis keuntungan usaha pengolahan pupuk bokashi. Sains Riset 1(2).

Pangaribuan D.H. , Yasir M. Utami N.K. 2012. Dampak bokashi kotoran ternak dalam pengurangan pemakaian pupuk anorganik pada budidaya tanaman tomat. J. Agron. Indonesia 40 (3) : $204-210$.

Sihombing. D. T. H. 1997, Ilmu Ternak Babi. Gajah Mada Univercity Press. Yogyakarta. 